\title{
Microcontroller Based Automatic Calculation of Ideal Weight Body
}

\author{
Muhamad Yusvin Mustar ${ }^{* 1}$, Anna Nur Nazilah Chamim ${ }^{1}$, Karisma Trinanda Putra ${ }^{2}$, Vendy Dwi \\ Hendra Nugraha $^{1}$, Yessi Jusman ${ }^{1}$ \\ ${ }^{1}$ Department of Electrical Engineering, Faculty of Engineering, Universitas Muhammadiyah \\ Yogyakarta \\ Bantul 55183 Daerah Istimewa Yogyakarta, Indonesia \\ ${ }^{2}$ College of Information and Electrical Engineering, Asia University \\ Liufeng Road 500, Wufeng District, Taichung City, Taiwan 41354 \\ *Corresponding author, e-mail: yusvin@umy.ac.id
}

\begin{abstract}
The development of science and technology is increasing every day, especially in the field of electronics and control systems. This is marked by the rapid progress that has occurred with the creation of increasingly sophisticated electronic devices and all systems have gone from conventional to automatic. Many benefits are obtained from the rapid development in the field of electronics and control systems including being able to assist humans in completing their tasks, increasing human productivity, and increasing the level of effectiveness in doing work. Departing from this, then in this study designed an automatic body ideal value calculation tool that is controlled by a microcontroller chip using $C$ language programming. This study provides another alternative in measuring mass values, height values, and displaying a BMI (Body Mass Index) ) subject automatically. The working system is quite easy where the subject only climbs the scales, the height measuring device with ultrasonic sensors PING)) will work to measure the subject's height, the scales equipped with the HX711 module will measure the mass value of the subject. Then, the microcontroller will process the height value, and the mass value of the subject to calculate the subject's BMI.
\end{abstract}

Keywords: Microcontroller, Subject, BMI Value, PING)) Ultrasonic Sensor, and HX711 Module

\section{Introduction}

Having an ideal body is everyone's dream whether they are young or old. Viewed from various aspects, someone who has an ideal body has more advantages than those who do not, for example, in terms of health, someone who has an ideal body must have a strong and healthy physique but someone who has a strong and healthy physique may not necessarily have ideal body, in terms of appearance, someone who has an ideal body certainly has a more attractive appearance than those who do not have an ideal body, and in terms of clothing needs, it is easier to find clothes that are suitable for someone of ideal body than those who are not ideal. Various methods have been carried out in order to achieve an ideal body either by regulating eating patterns, eating low-fat foods, strict diets, exercising regularly to taking drugs.

To find out the ideal value of the body, one must know the reference point of the ideal value itself, namely body height and body mass. Many people have taken measurements of height and body mass using scales but they don't know the measurements of whether their body is ideal or not. They only use approximate calculations to achieve the ideal body due to lack of knowledge and information about 
how to calculate the ideal body value. Scales that are often found only provide measurements of height and body mass without calculating the ideal body value.

The number of activities that use scales as a measurement tool such as athlete selection, sports club entrance selection, police school entrance selection, army school entrance selection, high school entrance selection and so on result in scales are still very necessary. However, the system which is still conventional (not automatic) causes the lack of sale value in the scales in the global era like today. Therefore, there is a need for a renewal of the scale in which there is a height gauge, a body mass gauge, an ideal body value calculator and an automatic system. By combining all these aspects, "Microcontroller-Based Automatic Body Ideal Counting Tool" is abbreviated as "PENITI's".

PENITI's is a series of electronics in the form of scales that have uses as a measure of body height, measuring body mass and calculating the ideal value of the body together with an automatic system. PENITI's itself is a renewal of the scales predecessor scales such as, scales to measure body mass only, scales to measure height and body mass without measuring ideal values, scales to measure height, mass, and display ideal body values that only use indicators without values the ideal itself, and so on. The automated system makes PENITI's it's easy to use. Someone just puts himself in front of the tool so the tool will automatically measure height and body mass, and displays the results of the calculation of the ideal body value in the form of values and states that the person is thin or fat. In making these measurements, PENITI's had very influential factors such as the use of sensors in the measurement as well as the working system, the use of chips as automatic controllers, the use of measurement value displays, and the use of mechanical systems. This paper describes PENITI's ability to determine height, body mass, BMI values, mechanical and automatic systems. PENITI's design describes the use of electronic components such as the HC-SR04 sensor as a measure of the distance of someone who wants to be measured, PING)) sensor Parallax as a height gauge, HX711 module which is equipped with a strain gauge as a body mass gauge, LCD as a measurement value display, and DC motor as a mechanical system. All components are connected to the ATMega16 Microcontroller as an automatic controller.

In the development of the scales system, the making of PENITI's is inseparable from studies that have been carried out by other people related to the scales such as in research conducted by Rahmat Alvian (2014), Arif Lukman Khakim (2015), and Febbi Tania Sipayung (2015).

First, research conducted by Rahmat Alvian explained that the scales he made could weigh sugar automatically. The research explains the form of the scales in the form of a prototype while PENITI's is a real form of the scales [1].

Secondly, research conducted by Arif Lukman Khakim explains about making digital scales using the ATMega32 Microcontroller as the controller. The research focused on the comparison of the weight value of objects with the value of the object price. In PENITI's design, the measurement is focused on the subject's mass value and the high value of the subject as well as the calculation of the subject's ideal body value [2].

Third, research conducted by Febbi Tania Sipayung explains the measurement of a person's height. The use of Arduino UNO as a controller and Ultrasonic as a sensor are the main components of the scales it makes. In PENITI's use ATMega16 Microcontroller as a controller and using the Ultrasonic sensor and Strain Gauge sensor as the main sensor [3].

With the research that has been done, PENITI's focuses on calculating the ideal body value based on the mass value and height of the subject with the ATMega16 Microcontroller as the main controller.

\section{Methods}

Flowchart for the research is presented in Fig. 1.

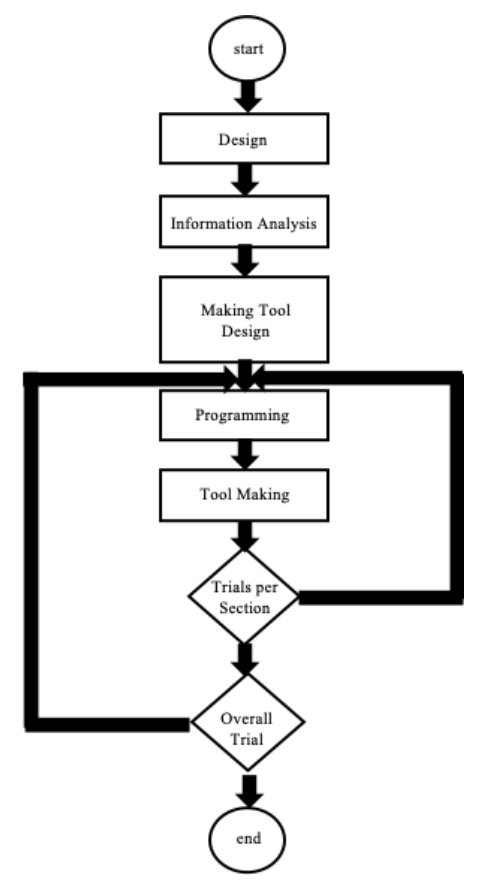

Fig. 1. Research flow chart 


\section{Design}

In this study began with the form planning, component layout and mechanical system layout from PENITI's

2. Information Analysis

Data and information obtained from information gathering are then carried out an information analysis process that functions to determine the form, material, and components used in PENITI's.

3. Making Tool Design

In this stage, the design of the tool is made to aim for the next step, which is making the tool so that it can know the legs of the interconnected components. Besides, it can also be seen the actual shape of the image from PENITI's.

4. Programming

After making the design of the tool, the process of making the program is carried out so that PENITI's can work as desired.

\section{Test Making}

At this stage, after the materials and components have been collected the process of making the tool is in accordance with PENITI's design that has been made.

6. Trials per Section

Tests per PENITI's part in the form of separate circuit parts before being put together into a single unit that is testing the upper and main controller circuit, but if there is still damage and needs to be repaired either the program or PENITI's.

7. Overall Trial

Tests per PENITI's part in the form of separate circuit parts before being put together into a single unit that is testing the upper and main controller circuit, but if there is still damage and needs to be repaired either the program or PENITI's.

\section{Results}

\section{III.1. Testing the Voltage Output of the LM2596 Regulator Module}

The LM2596 Regulator module is located on the top controller which functions to provide input voltage to several components on the top controller such as the ATMega16 microcontroller, PING)) Parallax sensor, HC-SR04 sensor, and L298N Module. The LM2596 Regulator module is connected to the battery as the input voltage provider and the LM2596 regulator module is used to reduce the input voltage. LM2596 Regulator Module Block Diagram is presented in Figure 2.

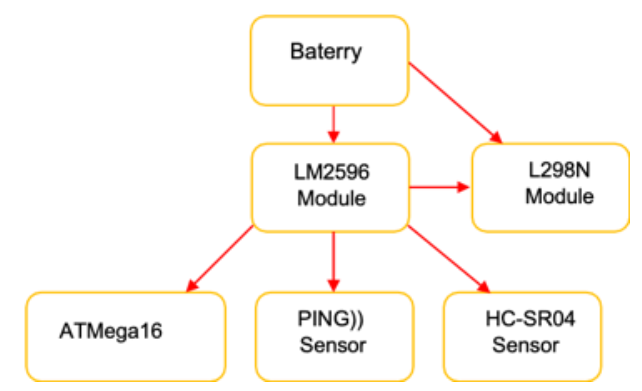

Fig. 2. LM2596 regulator module block diagram

LM2596 regulator module testing using a multimeter as presented in Table I and Figure 3.

TABLE I

Testing ON LM2596 Regulator Module

\begin{tabular}{cc}
\hline \hline Components Used & Voltage \\
\hline ATMega16 & $4.87 \mathrm{~V}$ \\
PING)) Parallax Sensor & $4.87 \mathrm{~V}$ \\
HC-SR04 Sensor & $4.87 \mathrm{~V}$ \\
L298N Module & $4.87 \mathrm{~V}$ and 12 V \\
\hline \hline
\end{tabular}

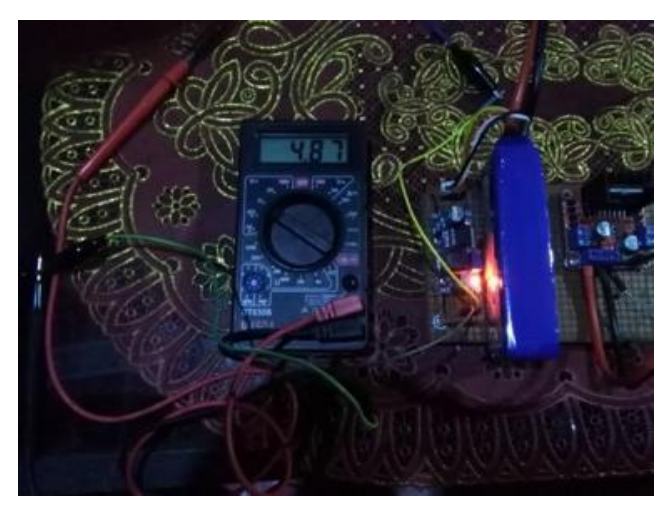

Fig. 3 . Testing the LM2596 regulator module output

From Table I, it can be seen that the LM2596 module output voltage value is enough to run the components, so that PENITI's can work as desired.

\section{III.2. LCD Testing}

LCD testing aims to determine the performance of both LCD LCD 2x16 and LCD 4x20 as a viewer of the height and mass measurement of the subject, as well as the viewer of the calculation of the ideal body value (BMI). The LCD is connected to the ATMega16 microcontroller to receive the results of the sensor data processing as presented in Figures 4 and 5 .

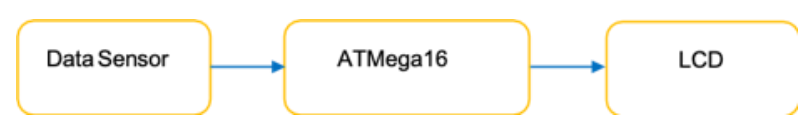

Fig. 4. LCD block diagram 


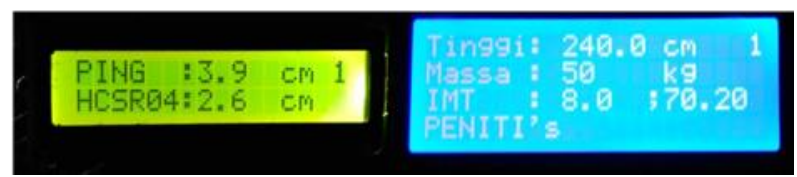

Fig. 5. Tests on LCD (a) 2x16 LCD (b) 4x20 LCD

From the tests in Figures 4 and 5, LCD 2x16 can display data from PING)) sensor readings Parallax and HC-SR04 sensors and LCD 4x20 can display data on the subject height value, subject mass value, BMI value, mass value that will be reduced, and indicator values.

\section{III.3. Testing the HX711 module}

The testing of the HX711 module which is connected to the strain gauge aims to determine the performance of the HX711 module as a pressurereading module with a strain gauge that functions to measure the mass of the PENITI's subject. This module is connected to the ATMega16 microcontroller on the main controller PENITI's which has a lower limit of $30 \mathrm{~kg}$. The lower limit serves to control the input of PENITI's. The HX711 Module Block Diagram is presented in Figure 6.

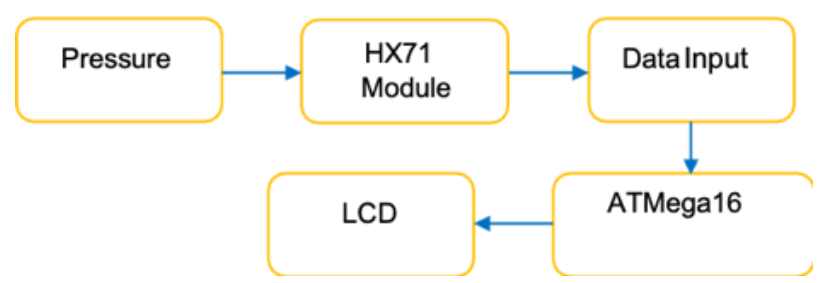

Fig. 6. HX711 module block diagram

The LM2596 regulator module testing uses a multimeter as presented in Tables II, III and IV.

TABLE II

COMPARISON OF MASS MEASUREMENT BETWEEN SCALES AND PENITI'S (FIRST EXPERIMENT)

\begin{tabular}{ccc}
\hline \hline \multicolumn{2}{l}{ Comparison $(\mathrm{Kg})$} & \multirow{2}{*}{ Error } \\
\cline { 1 - 2 } Scales & PENITI's & \\
\hline 0 & 28 & Not defined \\
10 & 37 & 2.7 \\
11 & 37 & 2.3 \\
52 & 80 & 0.53 \\
56 & 80 & 0.42 \\
61 & 90 & 0.47 \\
63 & 92 & 0.46 \\
70 & 98 & 0.4 \\
72 & 100 & 0.38 \\
74 & 104 & 0.4 \\
83 & 111 & 0.33 \\
Average Error & 0.84 \\
\hline \hline
\end{tabular}

TABLE III

Comparison of Mass Measurement Between Scales and PENITI'S (SECOND EXPERIMENT)

\begin{tabular}{ccc}
\hline \hline \multicolumn{2}{c}{ Comparison $(\mathrm{Kg})$} & \\
\cline { 1 - 2 } Scales & PENITI's & \\
\hline 0 & 17 & Not defined \\
10 & 28 & 1.8 \\
11 & 28 & 1.5 \\
52 & 67 & 0.28 \\
56 & 72 & 0.28 \\
61 & 77 & 0.26 \\
63 & 82 & 0.30 \\
70 & 88 & 0.25 \\
72 & 88 & 0.22 \\
74 & 92 & 0.24 \\
83 & 99 & 0.19 \\
Average Error & 0.53 \\
\hline \hline
\end{tabular}

TABLE IV

COMPARISON OF MASS MEASUREMENT BETWEEN SCALES AND PENITI'S (THIRD EXPERIMENT)

\begin{tabular}{ccc}
\hline \hline \multicolumn{2}{c}{ Comparison $(\mathrm{Kg})$} & \\
\cline { 1 - 2 } Scales & \multirow{2}{*}{ PENITI's } & \\
\hline 0 & 0 & Not defined \\
10 & 8 & 0.2 \\
11 & 9 & 0.18 \\
52 & 50 & 0.038 \\
56 & 54 & 0.035 \\
61 & 59 & 0.032 \\
63 & 63 & 0 \\
70 & 68 & 0.028 \\
72 & 70 & 0.027 \\
74 & 72 & 0.027 \\
83 & 81 & 0.024 \\
Average Error & 0.06 \\
\hline \hline
\end{tabular}

From the HX711 test connected to the strain gauge, the error value was obtained on PENITI's reading. Calculation of the error value is obtained using the formula:

Error Value $=\frac{(\text { Scales Value }- \text { PENITI's Value })}{(\text { Scales Value })}$

In all the experiments, there was a decrease in the error value on each measurement with the same subject. That can happen because of the calibration done on PENITI's. The function of the calibration is to reduce the error value at each reading of the tool and to get the same value between the reading of the tool with the original measurement. Comparison of Mass Value Measurement is presented in Figure 7. 


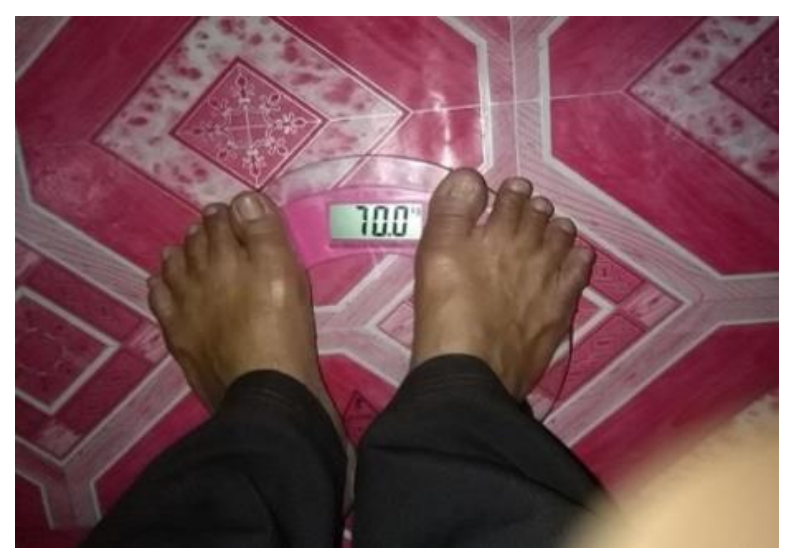

(a) Scales

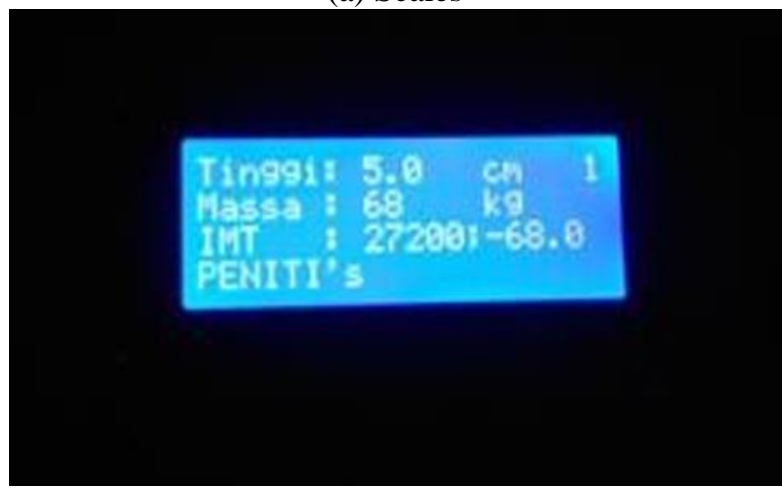

(b) PENITI's

Fig. 7. Comparison of mass value measurement

From Tables I, II, III and IV, it can be seen that the LM2596 module output voltage value is sufficient to run the component, so that PENITI's can work as desired.

\section{III.4. Testing of Telephone Spiral Cables as a Transceiver component}

This transceiver test aims to determine the performance of the transceiver that can work for communication between the microcontroller on the top controller and the main controller. The Transceiver Block diagram is presented in Figure 8.

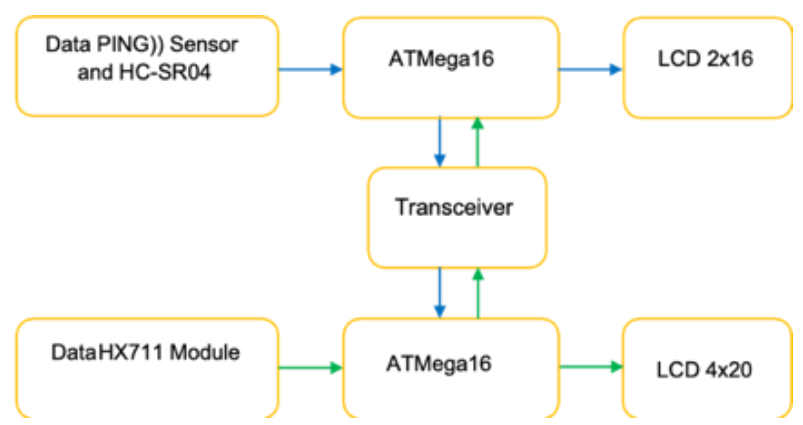

Fig. 8. Transceiver block diagram
TABLE V

Data Sent AND Received by the ATMega16 Microcontroller via a Telephone Spiral Cable

\begin{tabular}{cc}
\hline \hline $2 \times 16$ LCD & $4 \times 20$ LCD \\
\hline Transmitter : & Transmitter: \\
Data Sensor PING)) & Initializing Mass Value \\
Receiver: & Receiver : \\
Initializing Mass Value & Data Sensor PING)) \\
\hline \hline
\end{tabular}

From Table $\mathrm{V}$, in the serial communication experiment, there are 2 (two) transmissions, namely the upper controller (LCD $2 \times 16$ ), data sent in the form of PING)) sensor reading data) and the data received in the form of mass value initialization data and on the main controller (LCD $4 \times 20$ ), data sent in the form of data initialization mass value and the data received in the form of PING)) sensor data. The delivery process uses elastic telephone spiral wires. The mass initialization value is a logical value if the mass value is more than or equal to $30 \mathrm{~kg}$, it will be worth 1 (one) whereas if the mass value is less than $30 \mathrm{~kg}$, it will be worth 0 (zero). Initialization of the mass value is used so that it can be displayed on the 2x16 LCD as shown in Figure 9.

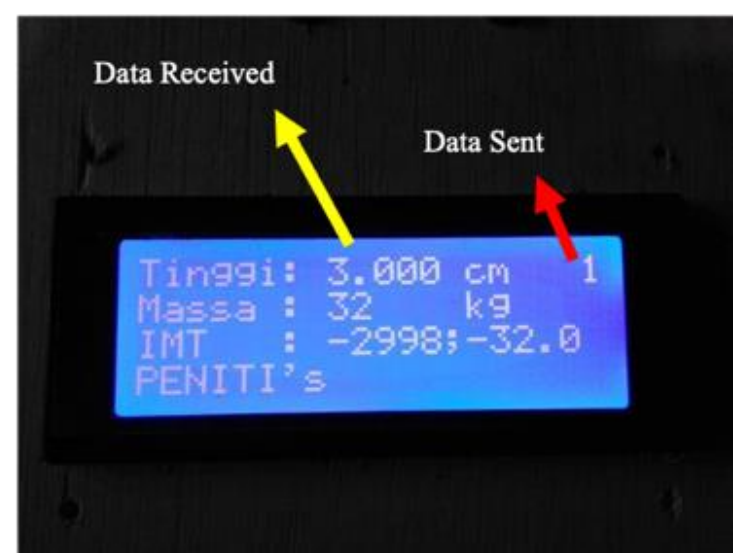

(a) Main Controller

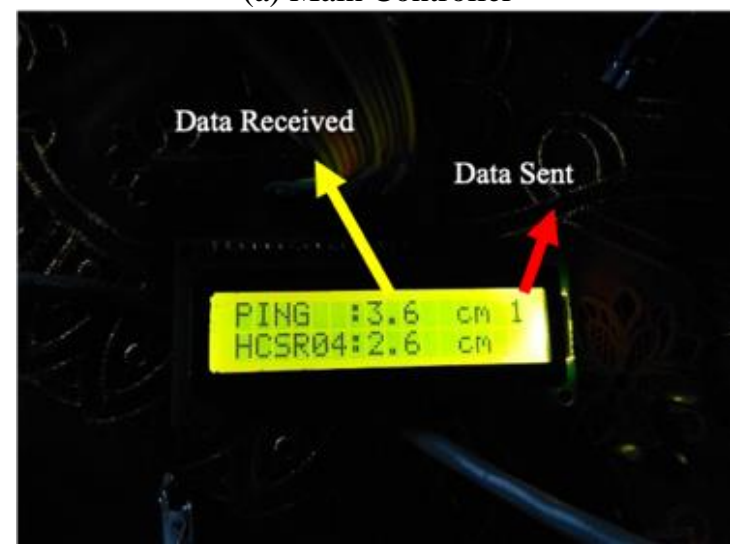

(b) Upper Controller

Fig. 9. LCD display of serial communication system 


\section{III.5. Testing the HX711 module}

L298N Module Testing aims to determine the performance of the L298N module as a controller (driver) of a DC motor. The logic entered in the L298N module is data processed by the ATMega16 microcontroller from the HC-SR04 sensor measurement and the HX711 module measurement connected to the strain gauge. The logic provided:

1. If the lower limit of the HC-SR04 sensor is met (between $0 \mathrm{~cm}$ to $50 \mathrm{~cm}$ ) and the lower limit of the HX711 module connected to the strain gauge is met $(30 \mathrm{~kg})$ then the $\mathrm{L} 298 \mathrm{~N}$ module will work and run the DC motor so that the controller of the PENITI's rises.

2. If the lower limit of the HC-SR04 sensor is not met (between $0 \mathrm{~cm}$ to $50 \mathrm{~cm}$ ) and the lower limit of the HX711 module connected to the strain gauge is also not met $(30 \mathrm{~kg})$ then the $\mathrm{L} 298 \mathrm{~N}$ module will work and run the DC motor so that the controller of the PENITI's goes down.

If one of the lower limits (either the HC-SR04 or HX711 sensor connected to the strain meter) is not met, then the L298N module will not function and the DC motor will automatically not function so the PENITI's controller will be stationary. The Module Block diagram is presented in Figure 10.

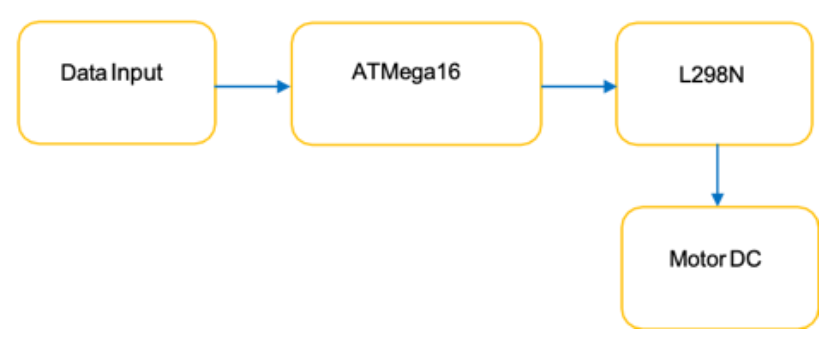

Fig. 10. Module block diagram

Conditions on the L298N Module and DC Motor when given logic as presented in Table IV and Figure 11.

TABLE VI

Comparison of Mass MEASUREMENT BetweEn SCALES AND PENITI's (FIRST EXPERIMENT)

\begin{tabular}{cccc}
\hline \hline \multicolumn{2}{l}{ L298N Module Logic } & $\begin{array}{c}\text { Multimeter } \\
\text { (V DC) }\end{array}$ & Motor DC \\
\cline { 1 - 2 } ENA1 & ENA2 & & \\
\hline 0 & 0 & 0 & Stop \\
0 & 1 & 11.8 & CW \\
1 & 0 & -11.8 & CCW \\
\hline \hline
\end{tabular}

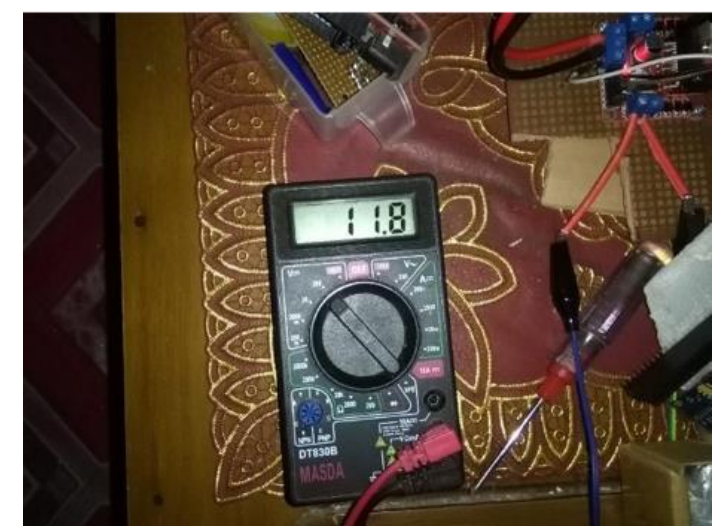

Fig. 11. L298N module output value when working

\section{III.6. PING)) Sensor Testing Parallax}

PING)) test Parallax sensor aims to determine the performance of PING)) Parallax sensor that measures distance as a high input value on PENIT. Data obtained from PING)) Parallax sensor is processed by an ATMega16 microcontroller and displayed on a $2 \times 16$ LCD. After it can be displayed on the $2 \times 16 \mathrm{LCD}$, it will be sent to the main controller to be displayed again on the $4 \times 20 \mathrm{LCD}$. PING)) Sensor Testing Parallax Block Diagram is presented in Figure 12. PING)) sequence Parallax sensor settings on the top controller and can be displayed on the 2x16 LCD are as follows:

1. Connecting the PING)) sensor pin Parallax on the ATMega16 microcontroller with the GIS pin connected to portD.7 as input data.

2. Connecting the LCD pin $2 \times 16$ on the microcontroller ATMega 16 on portC. 0 to portC. 2 and portC. 4 to portC.7.

3. Inserting PING)) sensor program Parallax on the ATMega16 microcontroller.

4. Run the program and make sure the PING)) sensor Parallax works.

5. Observing the results of PING)) sensor readings Parallax on the LCD.

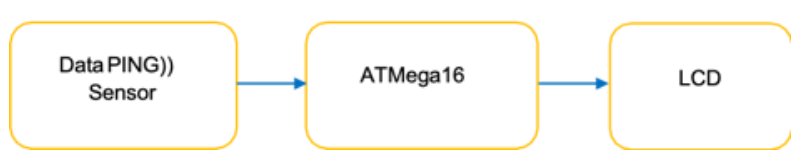

Fig. 12 . PING)) sensor testing parallax block diagram

From Table VII, the error value is obtained at PING)) Parallax sensor due to PING)) measurement limit The parallax sensor itself is $2 \mathrm{~cm}$ for the lower limit and $300 \mathrm{~cm}$ for the upper limit. Therefore, if there is a measurement outside the limit, an error will occur in the PING)) measurement Parallax sensor. PING)) Parallax Testing Sensor is presented in Figure 13. 
TABLE VII

PING)) Sensor Testing Parallax

\begin{tabular}{ccc}
\hline \hline $\begin{array}{c}\text { Ruler } \\
\text { Measurement }\end{array}$ & $\begin{array}{c}\text { PING) Sensor } \\
\text { Measurement }\end{array}$ & Error \\
\hline $1 \mathrm{~cm}$ & $1 \mathrm{~cm}$ & 1 \\
$2 \mathrm{~cm}$ & $2 \mathrm{~cm}$ & 0 \\
$3 \mathrm{~cm}$ & $3 \mathrm{~cm}$ & 0 \\
$4 \mathrm{~cm}$ & $4 \mathrm{~cm}$ & 0 \\
$5 \mathrm{~cm}$ & $5 \mathrm{~cm}$ & 0 \\
$6 \mathrm{~cm}$ & $6 \mathrm{~cm}$ & 0 \\
$7 \mathrm{~cm}$ & $7 \mathrm{~cm}$ & 0 \\
$8 \mathrm{~cm}$ & $8 \mathrm{~cm}$ & 0 \\
$9 \mathrm{~cm}$ & $9 \mathrm{~cm}$ & 0 \\
$10 \mathrm{~cm}$ & $10 \mathrm{~cm}$ & 0 \\
$11 \mathrm{~cm}$ & $11 \mathrm{~cm}$ & 0 \\
$12 \mathrm{~cm}$ & $12 \mathrm{~cm}$ & 0 \\
$13 \mathrm{~cm}$ & $13 \mathrm{~cm}$ & 0 \\
$14 \mathrm{~cm}$ & $14 \mathrm{~cm}$ & 0 \\
$15 \mathrm{~cm}$ & $15 \mathrm{~cm}$ & 0 \\
$16 \mathrm{~cm}$ & $16 \mathrm{~cm}$ & 0 \\
$17 \mathrm{~cm}$ & $17 \mathrm{~cm}$ & 0 \\
$18 \mathrm{~cm}$ & $18 \mathrm{~cm}$ & 0 \\
$19 \mathrm{~cm}$ & $19 \mathrm{~cm}$ & 0 \\
$20 \mathrm{~cm}$ & $20 \mathrm{~cm}$ & 0 \\
$21 \mathrm{~cm}$ & $21 \mathrm{~cm}$ & 0 \\
$22 \mathrm{~cm}$ & $22 \mathrm{~cm}$ & 0 \\
$23 \mathrm{~cm}$ & $23 \mathrm{~cm}$ & 0 \\
$24 \mathrm{~cm}$ & $24 \mathrm{~cm}$ & 0 \\
$25 \mathrm{~cm}$ & $25 \mathrm{~cm}$ & 0 \\
$26 \mathrm{~cm}$ & $26 \mathrm{~cm}$ & 0 \\
$27 \mathrm{~cm}$ & $27 \mathrm{~cm}$ & 0 \\
$28 \mathrm{~cm}$ & $28 \mathrm{~cm}$ & 0 \\
$29 \mathrm{~cm}$ & $29 \mathrm{~cm}$ & 0 \\
$30 \mathrm{~cm}$ & $30 \mathrm{~cm}$ & 0 \\
Average Error & 0.03 \\
\hline \hline & & \\
\hline
\end{tabular}

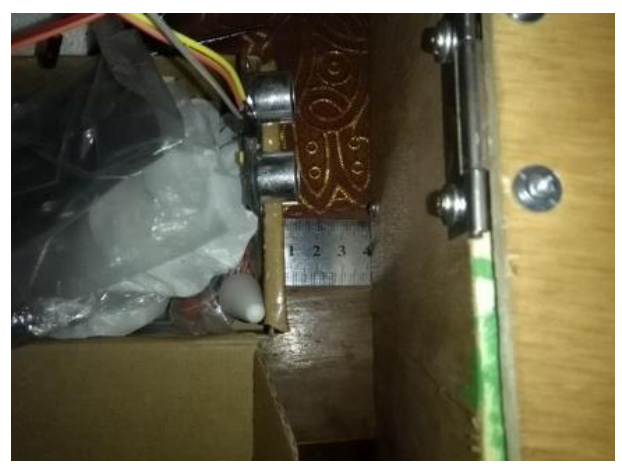

(a) Ruler

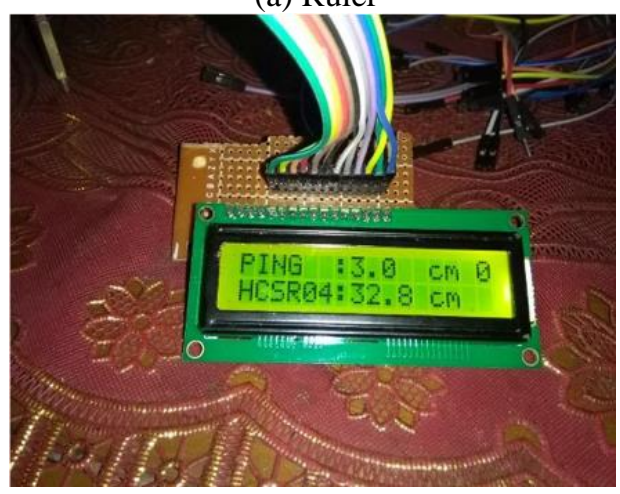

(b) 2x16 LCD Display

Fig. 13. PING)) sensor testing parallax

\section{III.7. Testing HC-SR04 Sensor}

HC-SR04 sensor testing aims to determine the performance of distance reading between the subject and the tool so that the tool can work in accordance with the given program. The distance value measured by the HC-SR04 sensor will be processed on the ATMegs16 microcontroller and displayed on the $2 \times 16$ LCD. Testing the HC-SR04 Sensor Block Diagram is presented in Figure 14. Measurement of the HC-SR04 sensor distance has certain limitations:

1. If the lower limit is met (between $0 \mathrm{~cm}$ to 50 $\mathrm{cm})$ then the controller of PENITI's works.

2. If it exceeds the lower limit (between $0 \mathrm{~cm}$ to $50 \mathrm{~cm}$ ) then the PENITI's controller will not work.

Both choices are also influenced by meeting the lower limit of the subject's mass of $30 \mathrm{~kg}$.

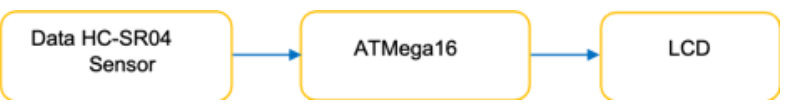

Fig. 14 . Testing HC-SR04 sensor block diagram

TABLE VIII

TESTING HC-SR04 SENSOR

\begin{tabular}{ccc}
\hline \hline $\begin{array}{c}\text { Ruler } \\
\text { Measurement }\end{array}$ & $\begin{array}{c}\text { PING) Sensor } \\
\text { Measurement }\end{array}$ & Error \\
\hline $1 \mathrm{~cm}$ & $372 \mathrm{~cm}$ & 371 \\
$2 \mathrm{~cm}$ & $375 \mathrm{~cm}$ & 186.5 \\
$3 \mathrm{~cm}$ & $3 \mathrm{~cm}$ & 0 \\
$4 \mathrm{~cm}$ & $4 \mathrm{~cm}$ & 0 \\
$5 \mathrm{~cm}$ & $5 \mathrm{~cm}$ & 0 \\
$6 \mathrm{~cm}$ & $6 \mathrm{~cm}$ & 0 \\
$7 \mathrm{~cm}$ & $7 \mathrm{~cm}$ & 0 \\
$8 \mathrm{~cm}$ & $8 \mathrm{~cm}$ & 0 \\
$9 \mathrm{~cm}$ & $9 \mathrm{~cm}$ & 0 \\
$10 \mathrm{~cm}$ & $10 \mathrm{~cm}$ & 0 \\
$11 \mathrm{~cm}$ & $11 \mathrm{~cm}$ & 0 \\
$12 \mathrm{~cm}$ & $12 \mathrm{~cm}$ & 0 \\
$13 \mathrm{~cm}$ & $13 \mathrm{~cm}$ & 0 \\
$14 \mathrm{~cm}$ & $14 \mathrm{~cm}$ & 0 \\
$15 \mathrm{~cm}$ & $15 \mathrm{~cm}$ & 0 \\
$16 \mathrm{~cm}$ & $16 \mathrm{~cm}$ & 0 \\
$17 \mathrm{~cm}$ & $17 \mathrm{~cm}$ & 0 \\
$18 \mathrm{~cm}$ & $18 \mathrm{~cm}$ & 0 \\
$19 \mathrm{~cm}$ & $19 \mathrm{~cm}$ & 0 \\
$20 \mathrm{~cm}$ & $20 \mathrm{~cm}$ & 0 \\
$21 \mathrm{~cm}$ & $21 \mathrm{~cm}$ & 0 \\
$22 \mathrm{~cm}$ & $22 \mathrm{~cm}$ & 0 \\
$23 \mathrm{~cm}$ & $23 \mathrm{~cm}$ & 0 \\
$24 \mathrm{~cm}$ & $24 \mathrm{~cm}$ & 0 \\
$25 \mathrm{~cm}$ & $25 \mathrm{~cm}$ & 0 \\
$26 \mathrm{~cm}$ & $26 \mathrm{~cm}$ & 0 \\
$27 \mathrm{~cm}$ & $27 \mathrm{~cm}$ & 0 \\
$28 \mathrm{~cm}$ & $28 \mathrm{~cm}$ & 0 \\
$29 \mathrm{~cm}$ & $29 \mathrm{~cm}$ & 0 \\
$30 \mathrm{~cm}$ & $30 \mathrm{~cm}$ & 0 \\
Average Error & 27.8 \\
\hline \hline
\end{tabular}


From Table VIII, the error value obtained on the HC-SR04 sensor is due to the measurement limits of the HC-SR04 sensor itself which is $2 \mathrm{~cm}$ for the lower limit and $400 \mathrm{~cm}$ for the upper limit. Therefore, if there is a measurement outside the limits, an error will occur in the measurement of the HC-SR04 sensor. Another disadvantage of the HCSR04 sensor is the low level of stability which causes the HC-SR04 sensor to tend to have a changing measurement value. Testing HC-SR04 Sensor is presented in Figure 15.

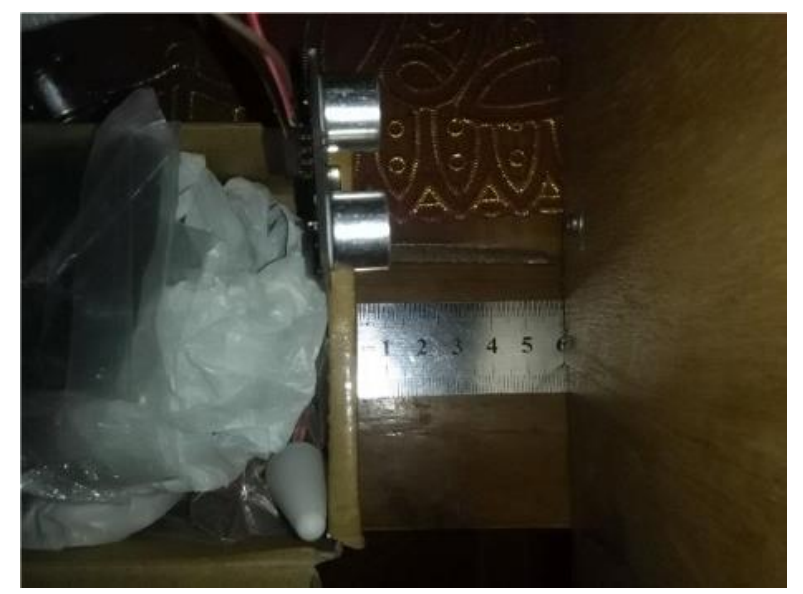

(a) Ruler

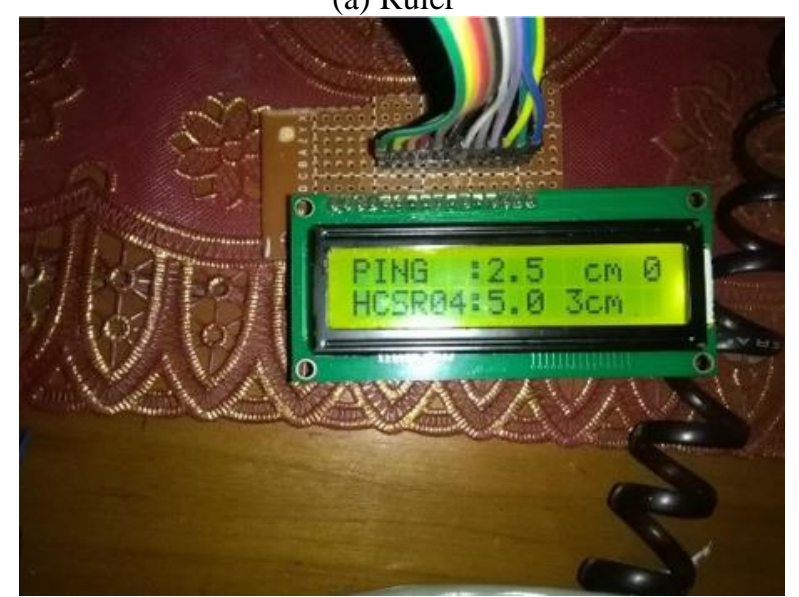

(b) 2x16 LCD Display

Fig. 15. Testing HC-SR04 sensor

\section{III.8. Testing of PENITI's main rankings}

Testing of PENITI's main ranks aims to find out the performance of the PING)) sensor readings as subject height data, HX711 readings that are connected with strain gauge as subject mass data, serial communication using telephone spiral wires, and IMT calculations which will later be displayed on a $4 \times 20$ LCD. Testing the PENITI's Main Ranking Block Diagram is presented in Figure 16.

In addition, the $4 \times 20$ LCD on PENITI's main circuit can display indicators of the subject's mass value, and the mass value that the subject must reduce as shown in Figure 17.

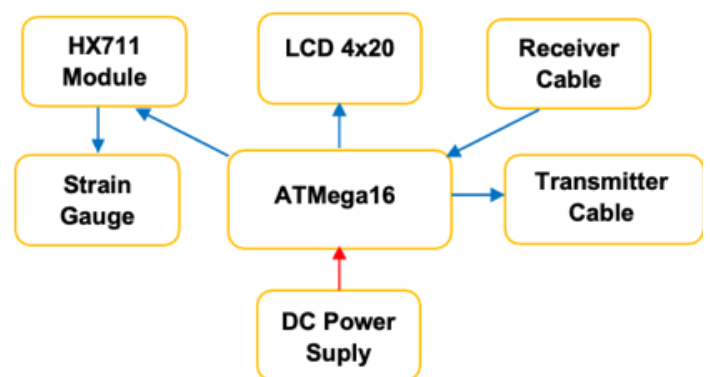

Fig. 16. Testing of PENITI's main rankings block diagram

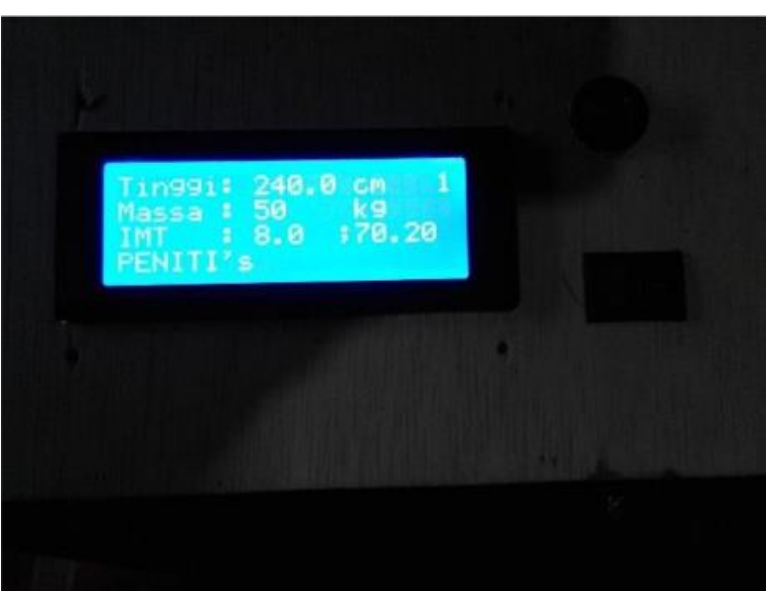

Fig. 17. Main controller display

\section{III.9. Testing the Circuit for PENITI's}

Testing of PENITI's main rank aims to determine the performance of the PING)) sensor readings as subject height data, HC-SR04 sensor reader as reading the distance of the tool to the subject which will then be displayed on the $2 \times 16$ LCD as shown in Figure 19. Testing the Circuit for PENITI's Block Diagram is presented in Figure 18.

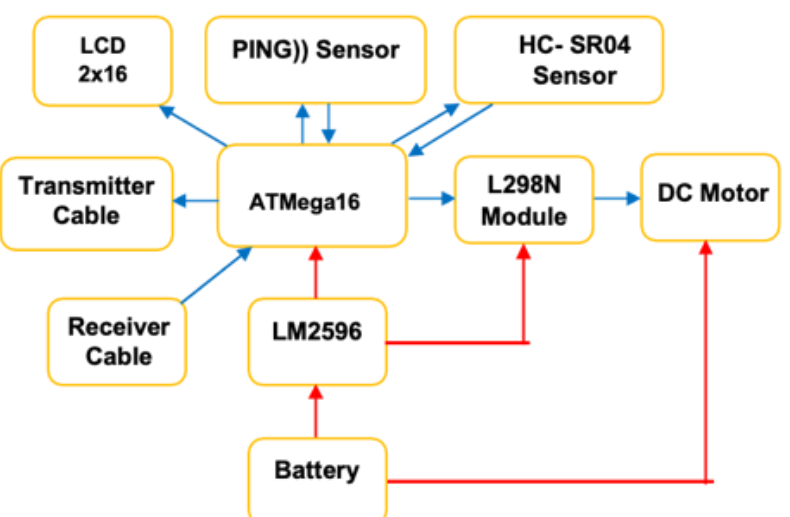

Fig. 18. Testing the circuit for PENITI's block diagram 


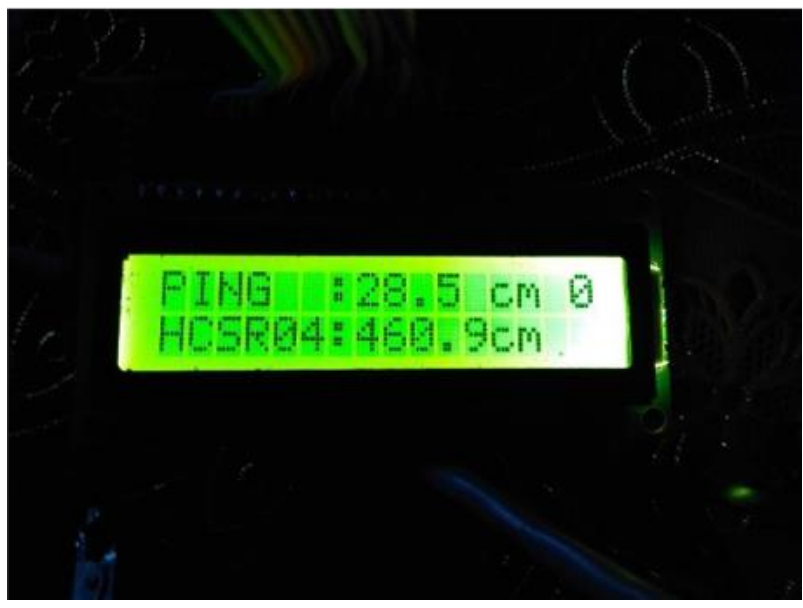

Fig. 19. Display top controller

\section{III.10.PENITI's Testing}

PENITI's test is the last test of the automatic body idel value counter based on the ATMega16 microcontroller. PENITI's is a combination of the top controller with the main controller that is connected with a telephone spiral cable to be able to communicate with each other, PENITI's testing is carried out in order to find out the performance of the device is ready to use or still needs to be improved. In PENITI's own, displayed the high value of the subject, mass of the subject, BMI value of the subject, mass indicator of the subject, the mass value of the subject to be reduced.

TABLE IX

TEST PENITI's By COMPARING PENITI'S WITH THE COMPARISON TOOL

\begin{tabular}{cccccc}
\hline \hline \multicolumn{2}{c}{ Comparison } & \multicolumn{4}{c}{ PENITIS's } \\
\hline $\begin{array}{c}\text { Height } \\
(\mathrm{cm})\end{array}$ & $\begin{array}{c}\text { Mass } \\
(\mathrm{kg})\end{array}$ & $\begin{array}{c}\text { Height } \\
(\mathrm{cm})\end{array}$ & $\begin{array}{c}\text { Mass } \\
(\mathrm{kg})\end{array}$ & IMT & Indicator \\
\hline 158 & 52 & 157 & 50 & 20 & Normal \\
170 & 83 & 170 & 81 & 28 & Fat \\
170 & 61 & 170 & 59 & 20 & Normal \\
169 & 70 & 169 & 68 & 23 & Normal \\
158 & 68 & 158 & 66 & 26 & Fat \\
\hline \hline
\end{tabular}

From Table IX, PENITI's testing is done using a comparison tool. For mass measurement, the comparison tool is in the form of an original scale, and for height measurement, the comparison tool is in the form of a meter. Compared to PENITI's purpose is to find out the value of PENITI'S with the original reference value, whether there is still an error value on PENITI's or not. PENITI's Testing Results as presented in Figures 20, 21 and 22.

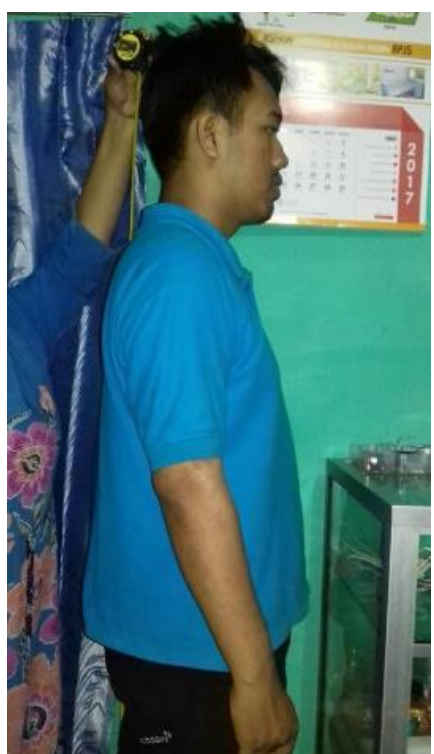

(a)

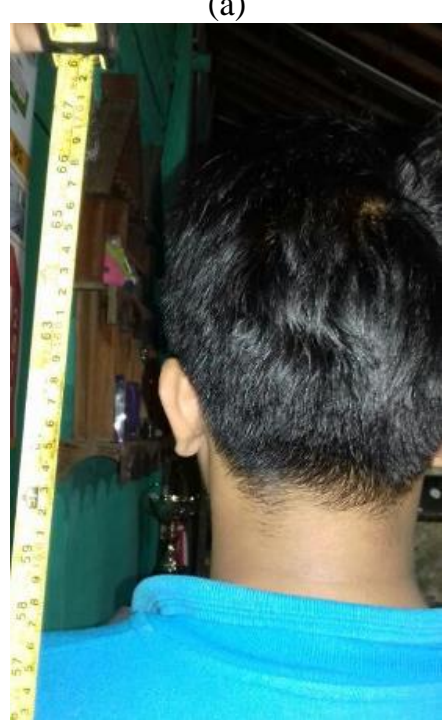

(b)

Fig. 20. Subject height testing with a comparison tool (meter) displayed $170 \mathrm{~cm}$

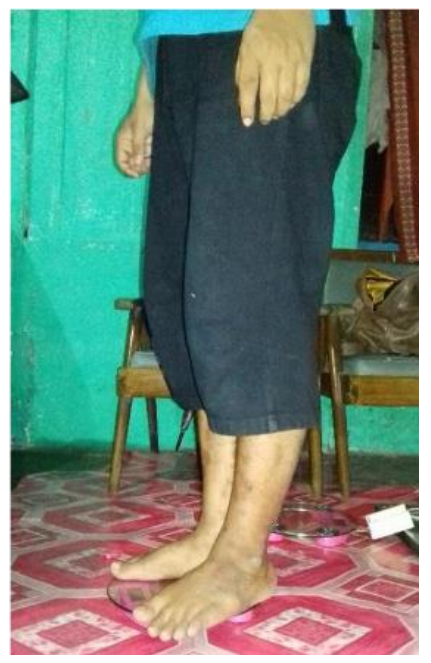

(a) 


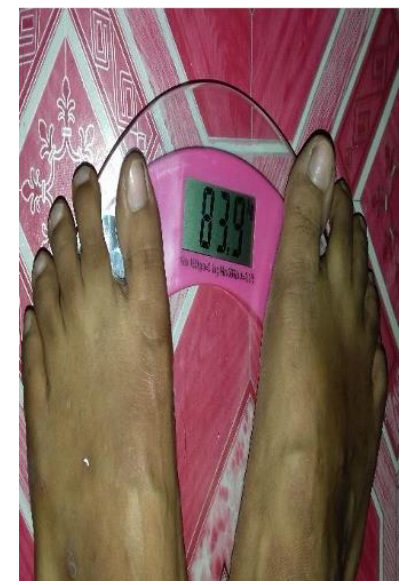

(b)

Fig. 21. Subject mass testing with comparators (scales) displayed $83 \mathrm{~kg}$

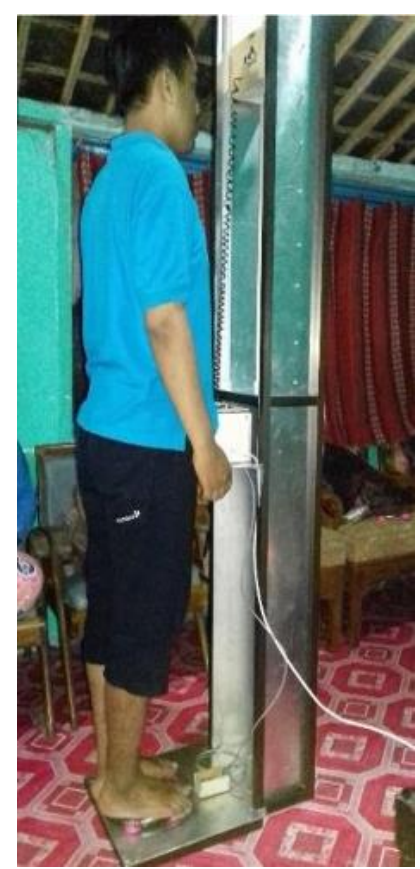

(a)

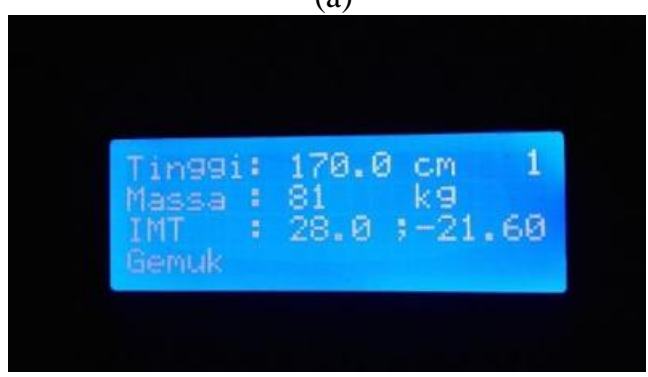

(b)

Fig. 22. Subject mass testing with PENITI's displayed: height $170 \mathrm{~cm}$, mass $81 \mathrm{~kg}$, BMI 28, and fat indicator

\section{Conclusion}

After planning and making PENITI's, then testing and analyzing PENITI's, it can be obtained several conclusions and suggestions that are expected to be useful in the future in order to improve PENITI's. The following are some conclusions obtained from testing and analysis:

1. PENITI's has been able to display the subject's high value, the subject's mass value, the subject's IMT value, the subject's mass indicator value, and the mass value that the subject has to reduce.

2. PENITI's has an average error value on the subject's mass reading ranging from $0.06 \%$.

3. PENITI's can communicate between series of controllers using telephone spiral wires

\section{Acknowledgements}

This work was supported by Universitas Muhammadiyah Yogyakarta.

\section{References}

[1] R. Alvian, "Prototipe Penimbang Gula Otomatis menggunakan Sensor Berat Berbasis ATMEGA16," 2018.

[2] A. L. Khakim, "Timbangan Digital Berbasis AVR Tipe ATMega32," 2015.

[3] F. T. Sipayung, "Rancang Bangun Alat Ukur Tinggi Badan Otomatis Berbasis Arduino Uno dan Ultrasonik," 2015.

\section{Authors' information}

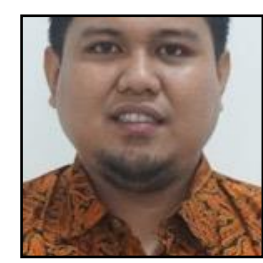

Muhamad Yusvin Mustar obtained his B. Eng in Electrical Engineering from Universitas Muhammadiyah Yogyakarta, Indonesia in 2011. His Master study was done at 2015 at the Electrical Engineering, Universitas Gadjah Mada, Indonesia. He currently is a lecture in department of electrical engineering, Universitas

Muhammadiyah Yogyakarta.

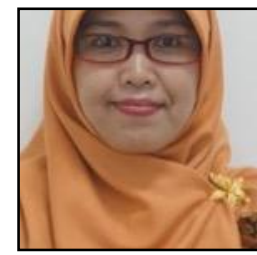

Anna Nur Nazilah Chamim obtained her B. Eng in Electrical Engineering from Universitas Muhammadiyah Yogyakarta, Indonesia. Her Master study was done at 2015 at the Electrical Engineering, Universitas Gadjah Mada, Indonesia. She currently is a lecture in department of electrical engineering, Universitas Muhammadiyah Yogyakarta.

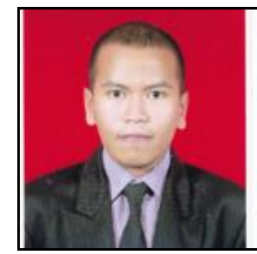

Karisma Trinanda Putra obtained his B. Eng in Electrical Engineering from Institut Teknologi Sepuluh Nopember, Indonesia in 2012. His Master study was done at 2015 at the Electrical Engineering, Institut Teknologi Sepuluh Nopember, Indonesia. He currently is a lecture in department of electrical engineering, Universitas Muhammadiyah Yogyakarta. 
Vendy Dwi Hendra Nugraha obtained his B. Eng in Electrical Engineering from Universitas Muhammadiyah Yogyakarta, Indonesia in 2017.

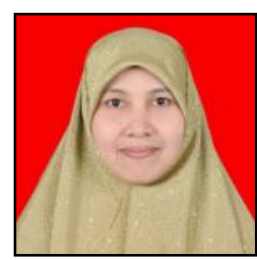

Yessi Jusman obtained her B. Eng in Electrical and Electronic Engineering from Andalas University, Indonesia in 2007. She worked as a Research Assistant started in July 2008 until November 2009 in Universiti Sains Malaysia. Her Master study was done at 2012 at the School of Electrical and Electronic Engineering, USM Engineering Campus in Nibong Tebal, Penang, Malaysia. She was finished her $\mathrm{PhD}$ degree at 2016 in University of Malaya with specializes in Image, Signal Processing, and algorithms. She currently is a lecture in department of electrical engineering, Universitas Muhammadiyah Yogyakarta. 